\title{
Squamous cell carcinoma in chronic ulcers in leprosy: a review of 38 consecutive cases
}

\author{
J H RICHARDUS \& T C SMITH \\ McKean Rehabilitation Centre, PO Box 53, Chiang Mai 50000, \\ Thailand
}

\author{
Accepted for publication 17 May 1991
}

\begin{abstract}
Summary The histories of 38 consecutive cases of squamous cell carcinoma (SCC) arising in chronic ulcers of leprosy patients treated between 1981 and 1990 at the McKean Rehabilitation Centre, Northern Thailand were analysed retrospectively. The study included 37 individual patients; 29 males and 8 females. The average age was 60 years, the average duration of leprosy was 34 years and the average duration of ulcers was 12 years. Most patients (76\%) came from leprosy settlements. Patients with borderline-tuberculoid (BT) leprosy were most commonly affected (63\%), followed by lepromatous (LL) leprosy $(21 \%)$ and borderline-lepromatous (BL) leprosy ( $16 \%)$. Four patients (11\%) had histories of SCC on other extremities. Metastatic spread was observed in 2 cases $(5 \%)$, both instances leading to death. The commonest site of involvement of SCC was the foot, but it was seen on the knee in 1 patient and on the hand in 2 others.

The incidence rate of SCC in the group at risk (leprosy patients with disability grading 1 and 2 ) is calculated as being $0 \cdot 79: 1000$ per year. SCC was seen in $1.8 \%$ of all cases admitted for ulcer care at the Centre. Treatment is by radical amputation.

SCC in chronic ulcers in leprosy patients cannot be considered rare and emphasizes the need for an active policy of disability prevention in leprosy programmes.
\end{abstract}

\section{Introduction}

Squamous cell carcinoma (SCC) developing in chronic ulcers of leprosy patients was first described in 1942. ${ }^{1}$ Only in 1964 was it mentioned again explicitly, in an article reporting on the case histories of 4 patients in India. ${ }^{2}$ Since then several articles have appeared on the subject, mostly from India and mainly they are accounts of individual cases. ${ }^{3-24}$ Only three articles have dealt with a larger series of patients, 13, 16 and 12 cases respectively. ${ }^{5,9,18}$ At the present time (1991) about 76 instances of SCC in leprosy have been reported. It would appear from the evidence of published case reports that the incidence of SCC in leprosy is very low. It has been mentioned by several authors that the complication is perhaps commoner than the literature suggests, but there are no epidemiological studies available to shed more light on this matter. In this paper we report 
on 38 consecutive cases of SCC in chronic ulcers of leprosy patients seen at our centre between 1981 and 1990. It is a retrospective study primarily aimed to elicit some of the epidemiological circumstances concerning SCC in patients with leprosy.

\section{Patients}

The McKean Rehabilitation Centre in Chiang Mai, Northern Thailand, has been a (church-related) treatment institute for leprosy patients since 1908. It serves patients from the Northern Thailand area (population approximately 10 million). The case histories of all leprosy patients admitted to the Centre from 1981 to 1990 and diagnosed with squamous cell carcinoma in a chronic ulcer were reviewed. The diagnosis was made clinically and usually confirmed histologically by the Pathology Department of Chiang Mai University Hospital. SCC arising from other skin conditions in leprosy patients (such as Bowen's disease, as seen in 2 cases during the study period), were not included.

\section{Results}

A total of 38 cases of SCC in chronic ulcers were seen during the 10-year period, involving 37 individual patients (Table 1). All patients came from Northern Thailand. Of the 37 patients, $29(78 \%)$ were males and $8(22 \%)$ females. The average age (male and female) at time of diagnosis was 60 years (ranging from 36 to 82 years); the average age of males was 61 years (ranging from 44 to 82 years), the average age of females was 56 years (ranging from 36 to 61 years). Of all patients, 28 (76\%) came from special leprosy settlements, the others lived independently. The distribution of the leprosy classification (Ridley-Jopling) was as follows (see also Table 4): borderline-tuberculoid (BT): 24 (63\%); borderlinelepromatous (BL): $6(16 \%)$ and lepromatous (LL): $8(21 \%)$. The average duration of leprosy at the time of diagnosis was 34 years, ranging from 10 to 60 years. The average duration of the ulcer was 12 years, ranging from 1 to 40 years. All but 2 patients had been treated with dapsone at some stage and all were skin-smear negative.

Four patients $(11 \%)$ had a history of SCC in a chronic ulcer on another extremity: 3 were diagnosed in the decade preceding our investigation period; 1 patient (a male with BT leprosy) was diagnosed with SCC twice during the 10-year period-in 1985 on the left hand and in 1988 on the right foot. In 35 cases (92\%) the SCC was localized on the foot

Table 1. Instances, per year, of squamous cell carcinoma in chronic ulcers diagnosed at the McKean Rehabilitation Centre

\begin{tabular}{|c|c|c|c|c|c|c|c|c|c|c|}
\hline & \multicolumn{10}{|c|}{ Year } \\
\hline & 1981 & 1982 & 1983 & 1984 & 1985 & 1986 & 1987 & 1988 & 1989 & 1990 \\
\hline Male & 2 & 3 & 4 & 3 & 4 & 1 & 1 & 5 & 4 & 3 \\
\hline Female & 0 & 0 & 0 & 0 & 1 & 5 & 0 & 1 & 0 & 1 \\
\hline Total & 2 & 3 & 4 & 3 & 5 & 6 & 1 & 6 & 4 & 4 \\
\hline
\end{tabular}


(right foot: 12, left foot: 23). The tumour was explicitly described as being on the forefoot in 15 cases and in 5 cases on the heel. In the remaining cases the tumour was either localized elsewhere on the foot (mid-sole, dorsum or ankle) or it was not possible to determine the origin of the tumour exactly due to its extent. In 1 case the SCC was localized on the extensor side of the left knee and in 2 cases on the palm of the left hand.

The appearance of the ulcer was described as 'fungating' or 'cauliflower growth' in 20 patients. Other, less explicit, descriptions were used in the remaining cases such as: 'nonhealing ulcer', 'suspicious ulcer' etc. Secondary spread of the cancer was seen in 2 patients $(5 \%)$; in both cases it lead to death.

The first patient was a 62-year-old male from a leprosy colony classified with borderline-tuberculoid (BT) leprosy of 40 years duration. Ulcers on the right foot had existed for at least 20 years. In 1981 he was admitted and diagnosed on clinical grounds with a squamous cell carcinoma on the right sole. No mention was made of enlarged inguinal nodes. A below knee amputation was performed and the patient was discharged after a normal recovery. He was seen again 4 years post-operative with a large ulcer in the popliteal fossa of the right leg and large, hard inguinal glands, also on the right side. Biopsy of the ulcer revealed a squamous cell carcinoma, moderately differentiated. An above knee amputation was done, but soon after multiple hard subcutaneous nodules appeared between the suture line and the groin. The general condition of the patient deteriorated rapidly and he died 4 weeks after surgery. The cause of death was registered as metastasis of squamous cell carcinoma primarily located in the right foot.

The second patient was a 58-year-old male, classified with lepromatous (LL) leprosy of 25 years duration. He had had ulcers on the left foot for at least 17 years. When he was seen by us his left foot had almost ulcerated away and only a foul-smelling mass was visible. He had large, painful inguinal nodes on the left side. A below knee amputation was done and the stump recovered well. The inguinal nodes, however, continued to grow. Three months post-operative they were described as hard, irregular, lobulated and some with fluctulent centres. The tumour grew slowly over the next year and started to ulcerate and become more painful. His general condition remained stable and the patient ref used all medical assistance. Sixteen months after the operation his condition deteriorated; he started to lose weight and a persistent cough developed. He died 2 months later. Death was registered as being caused by secondary metastatic spread of squamous cell carcinoma of the left foot. No autopsy was carried out.

By 1991 none of the other patients had died from reasons related to the SCC for which they were treated.

Histological confirmation of the diagnosis was obtained in $28(74 \%)$ cases. In all cases the pathologist reported squamous cell carcinoma, in 23 cases described as being well differentiated. In 1 case it was characterized as 'infiltrating', in 1 case as 'moderately differentiated' and in the remaining 3 reports no further specification was given.

\section{Discussion}

This study confirms previous observations that SCC in leprosy patients arise in ulcers of long duration. The average duration of the ulcer was 12 years. In reality this average duration was probably higher, because in order to establish the duration of an ulcer, only figures relating to ulcers observed and reliably recorded in the clinical notes were 
considered. In fact, many ulcers may have existed longer. On the other hand, ulcers often healed for some time only to break down again. Thus the 'duration of ulcer' refers to the period during which there was definite ulceration at the site involved. It was not possible to determine accurately the time when malignant transformation occurred. Usually the patients were not aware of any particular change apart from the fact that the ulcer gradually became worse. The average age of the patients was 60 years and the average duration of leprosy 34 years. More males were affected than females.

The 'pool' of leprosy patients serviced by the Centre was 6190 at the beginning of 1981 and had increased to 6862 by the end of 1990 . This increase $(11 \%)$ takes into account both the number of new registrations and the number of deaths reported to us. The percentage with disability in this group (grade 1 or 2 as defined by the $\mathrm{WHO}^{25}$ ) is $78 \%$. This figure did not change between 1981 and 1990. The group at risk (at the beginning of 1981) of developing or having ulcers can therefore be put at 4834 . The number of instances of SCC diagnosed during the 10 -year period was 38 or an average of 3.8 per year. The incidence rate of SCC amongst the population at risk is therefore $0.79: 1000$ per year (Table 2). The incidence rate in females is only slightly less than in males, the difference not being significant. The age group specific rates are given in Table 3. The highest incidence rate is in the age group 60-69 years: 1.93:1000 per year. SCC occurred most frequently in

Table 2. Incidence rate of squamous cell carcinoma in the group at risk (leprosy patients with disability grading 1 and 2)

\begin{tabular}{lccccc}
\hline & $\begin{array}{c}\text { Total no. } \\
\text { of patients }\end{array}$ & $\begin{array}{c}\text { Disability } \\
\text { grading } 0\end{array}$ & $\begin{array}{c}\text { Disability } \\
\text { grading 1 and } 2 \\
\text { (risk group) }\end{array}$ & $\begin{array}{c}\text { Instances } \\
\text { of SCC }\end{array}$ & $\begin{array}{c}\text { Incidence rate } \\
\text { per 1000 per year }\end{array}$ \\
\hline Male & 4439 & 907 & 3532 & 30 & $0 \cdot 85$ \\
Female & 1751 & 449 & 1302 & 8 & $0 \cdot 61$ \\
\hline Total & 6190 & 1356 & 4834 & 38 & $0 \cdot 79$ \\
\hline
\end{tabular}

Table 3. Incidence rate of squamous cell carcinoma in the group at risk (leprosy patients with disability grading 1 and 2)

\begin{tabular}{cccccc}
\hline $\begin{array}{c}\text { Age group } \\
\text { (years) }\end{array}$ & $\begin{array}{c}\text { Total no. of } \\
\text { patients }\end{array}$ & $\begin{array}{c}\text { Disability } \\
\text { grading } \\
0\end{array}$ & $\begin{array}{c}\text { Disability } \\
\text { grading 1 and } 2 \\
\text { (risk group) }\end{array}$ & $\begin{array}{c}\text { Instances } \\
\text { of SCC }\end{array}$ & $\begin{array}{c}\text { Incidence rate } \\
\text { per 1000 per year }\end{array}$ \\
\hline $0-9$ & 21 & 15 & 6 & 0 & 0 \\
$10-19$ & 232 & 145 & 87 & 0 & 0 \\
$20-29$ & 680 & 262 & 418 & 0 & 0 \\
$30-39$ & 1119 & 266 & 853 & 1 & $0 \cdot 12$ \\
$40-49$ & 1526 & 273 & 1253 & 4 & $1 \cdot 39$ \\
$50-59$ & 1301 & 100 & 671 & 13 & $1 \cdot 93$ \\
$60-69$ & 775 & 64 & 339 & 4 & $0 \cdot 82$ \\
$70-79$ & 403 & 11 & 122 & 1 & 0.79 \\
$>80$ & 133 & 1356 & 4834 & 38 & \\
\hline Total & 6190 & & & & \\
\hline
\end{tabular}


Table 4. Incidence rate of squamous cell carcinoma in the group at risk (leprosy patients with disability grading 1 and 2), using the Ridley-Jopling leprosy classification

\begin{tabular}{|c|c|c|c|c|c|}
\hline Classification & $\begin{array}{l}\text { Total no. of } \\
\text { patients }\end{array}$ & $\begin{array}{l}\text { Disability } \\
\text { grading } \\
0\end{array}$ & $\begin{array}{c}\text { Disability } \\
\text { grading } 1 \text { and } 2 \\
\text { (risk group) }\end{array}$ & $\begin{array}{c}\text { Instances } \\
\text { of SCC }\end{array}$ & $\begin{array}{l}\text { Incidence rate } \\
\text { per } 1000 \text { per year }\end{array}$ \\
\hline TT & 1137 & 346 & 791 & 0 & 0 \\
\hline BT & 1394 & 208 & 1186 & 24 & $2 \cdot 02$ \\
\hline $\mathrm{BB}$ & 270 & 83 & 187 & 0 & 0 \\
\hline $\mathrm{BL}$ & 1025 & 228 & 797 & 6 & 0.75 \\
\hline LL & 2122 & 422 & 1700 & 8 & $0 \cdot 47$ \\
\hline $\mathrm{U}^{*}$ & 242 & 69 & 173 & 0 & 0 \\
\hline Total & 6190 & 1356 & 4834 & 38 & 0.79 \\
\hline
\end{tabular}

* Unknown, other (indeterminate, pure neural).

borderline-tuberculoid (BT) patients (Table 4). The incidence rate in the BT group was 2.02: 1000 per year. Borderline-lepromatous (BL) was less commonly involved with an incidence rate of 0.75:1000 per year, and lepromatous leprosy (LL) patients showed an incidence rate of only 0.47:1000 per year. The finding of high involvement of patients in the total borderline group (BT and $\mathrm{BL}$ ) is in accordance with previous reports and most likely reflects the degree of nerve damage (anaesthesia) as frequently found in borderline cases. During the 10-year study period there were 2129 admissions in the Centre for ulcer care. The percentage of admissions for treatment of ulcers being malignant was 38 out of 2129 or $1.8 \%$. There was no significant change in frequency during the 10 -year study period.

Of all patients diagnosed with SCC, 28 (76\%) came from special leprosy settlements or colonies. In Northern Thailand both the Thai government and non-governmental organizations have settlements. The total number of patients living in these settlements is approximately 1100 . Virtually all the patients have disabilities because this was of ten the reason for them entering the settlement. Most members of these settlements would be referred to the McKean Rehabilitation Centre for treatment requiring hospitalization, especially in the case of ulcers. The incidence rate of SCC amongst this group is 2.55: 1000 per year.

The tumours were usually localized on the foot, the most common site of neuropathic ulcers in leprosy patients. In contrast to the report of Fleury \& Opromolla, ${ }^{9}$ the proximal third of the foot was not the commonest site of involvement in our group; the heel was identified as the origin of the tumour in only 5 cases, while the forefoot was affected in 15 cases. Interestingly, the left foot was involved nearly twice as often as the right foot. In 2 cases, the tumour was on the palm, a feature only reported once before. ${ }^{12}$

Another noteworthy finding was that 4 patients had SCC on different (unrelated) sites, diagnosed either before or during the 10-year study period. One wonders if, apart from the time factor, genetic or environmental factors are involved in the pathogenesis of these cancers in chronic ulcers.

The prognosis after treatment of SCC, usually by amputation, is very good. However, 2 patients in our series $(5 \%)$ died from metastatic spread of the cancer, highlighting the potential danger of this complication. On the other hand, secondaries only seem to occur 
after several years and early, radical treatment should be able to avoid this happening. Regional lymph nodes are often enlarged due to the infected tumour on the extremity. These septic lymph nodes settle down after the primary focus of infection is removed. It is not routine in the Centre to take biopsies from these nodes, following the advice of Andersen ${ }^{8}$ to leave these 'severely alone' in order to prevent chronic, fistulating lesions. Only when regional lymph nodes fail to resolve after amputation, is further histological investigation indicated.

Pathohistological examination, done in $74 \%$ of our cases, was usually reported as squamous cell carcinoma, well differentiated. In the remaining $26 \%$ no biopsy was taken because the clinical diagnosis seemed adequate and treatment (amputation) would not have been influenced by the pathology report because of the size and extent of the tumour. It has been argued that so-called malignant growths arising in chronic ulcers in some cases are really instances of pseudoepitheliomatous hyperplasia. ${ }^{5,21}$ This is considered benign and therefore would justify a more conservative approach in treatment such as local excision or repeated curettage. But Fleury \& Opromolla ${ }^{9}$ remark that the distinction between a hyperplastic pseudoepitheliomatous reactivity and a well-differentiated carcinoma is very difficult in preoperative biopsies. They analysed their cases on the infiltrative features of the epithelial projections of the tumours and considered the lesions malignant by analogy with other human neoplasms such as the giant condyloma acuminatum and the epithelioma cuniculatum pedis. We encountered this problem of distinction in one case where the initial biopsy as reported was, "chronic and acute inflammation with pseudoepitheliomatous hyperplasia'. A second biopsy, taken only 1 month afterwards, was reported as showing a well-differentiated squamous cell carcinoma. In another biopsy report it was explicitly noted that 'most areas have the appearance of pseudocarcinomatous hyperplasia, with differentiated cells and inflammatory infiltration. However, small foci of true squamous cell carcinoma are present, which are poorly demarcated from the surrounding stroma. These cells show individual keratization and atypia of nuclei'. It is clear that biopsy reports cannot be conclusive in deciding on therapeutical measures. Biopsies are not always from the right location or not taken deep enough into the tumour mass, and pathological features can be difficult to interpret. Clinical features such as the extent of the ulcerous fungating process and radiological evidence of bone involvement must be taken into consideration. We are in favour of radical amputation, either of the forefoot (if possible) or otherwise below the knee. With the availability of a good prosthesis workshop, disability can be kept to a minimum.

In summary one could say that the profile of our 'typical' leprosy patient with SCC is a 60 -year-old male with borderline-tuberculoid (BT) leprosy of 34 years duration, living in a leprosy colony. There have been (plantar) ulcer problems for at least 12 years before presenting with SCC.

The incidence rate among the risk group (leprosy patients with disability grading 1 and 2) is 0.79: 1000 per year. Of all patients with ulcers admitted to the Centre, $1.8 \%$ were diagnosed as having a malignant ulcer. SCC in chronic ulcers of leprosy patients cannot be considered rare and should be recognized in time. They lead to considerable disability (amputation, often below the knee) and even to death in 5\% of the cases due to metastatic spread. The occurrence of SCC in chronic ulcers emphasizes once again the need for an active policy of disability prevention in leprosy programmes. 


\section{References}

${ }^{1}$ Hayashi Y, Fukuda S. Cancroid from leprotic mal perforans du pied. La Lepro, 1942; 13: 9.

2 Job CK, Riedel RG. Squamous cell carcinoma arising in plantar ulcers in leprosy. Int J Lepr, 1964; 32: $37-44$.

3 Riedel RG. An additional note on malignancy in plantar ulcers in leprosy. Int J Le pr, 1966; 34: $287-8$.

${ }^{4}$ Michalany J. Malignant tumours of the skin among leprosy patients. Int J Lepr, 1966; 34: 274-86.

5 Srinivasan H, Desikan KV. Cauliflower growths in neuropathic plantar ulcers in leprosy. J Bone Joint Surg, 1971; 53: 123-32.

6 Boopalray JM, Muthusami TC. Squamous cell carcinoma arising from trophic ulcers. Lepr India, 1979; 51: 74-7.

7 Troy JL, Grossman ME, Walter RR. Squamous-cell carcinoma arising in a leprous neurotrophic ulcer: report of a case. J Dermatol Surg Oncol, 1980; 6: 659-61.

8 Andersen JG. Malignant degeneration in chronic ulceration of the leg and foot in leprosy patients; two case reports. Lepr Rev, 1982; 53: 265-9.

9 Fleury RN, Opromolla DVA. Carcinoma in plantar ulcers in leprosy. Lepr Rev, 1984; 55: 369-78.

${ }^{10}$ Kumar K, Kant M. Squamous cell carcinoma developing in trophic ulcers in leprosy: a case report. Ind J Lepr, 1984; 56: 656-7.

11 Bobhate SK, Sisodia SM, Kherdekar M. A case of squamous cell carcinoma in plantar ulcer in leprosy. Ind J Lepr, 1984; 56: 653-5.

12 Reddy NBB, Srinivasan T, Krishnan SAR. Bhusnurmath SR. Malignancy in chronic ulcers in leprosy: a report of 5 cases from Northern Nigeria. Lepr Rev, 1985; 56: 249-53.

13 Anilkumar G, Patil SD. Squamous cell carcinoma developing in trophic ulcer in leprosy: a case report. Ind $J$ Lepr, 1985; 57: 879-82.

14 Mohamed KN. Malignant transformation of plantar ulcers in leprosy. Singapore Med J, 1987; 28 : $432-5$.

15 Arora SK, Mukhija RD. Squamous cell carcinoma in trophic ulcer cases. Ind J Le pr, 1987; 59: 100-2.

16 Ozkan T, Yuksel A, Saylan T, Erding N, Sutlas M, Mat C. Carcinoma in plantar ulcers of leprosy patients: a report of 4 cases from Turkey. Lepr Rev, 1988; 59: 356-7.

17 Majoroh TO, Imongan WI. Carcinoma in plantar ulcers of leprosy patients. Trop Geogr Med, 1988; 40: 365-8.

18 Sane SB, Mehta JM. Malignant transformation in trophic ulcers in leprosy: a study of 12 cases. Ind J Lepr, 1988; 60: 93-9.

19 Anilkumar G, Khedker MY, Bhume JI, Jawade GK. Malignant transformation of trophic ulcer in leprosy. Ind J Lepr, 1988; 60: 385-8.

20 Naik R, Bharathi S, Bai BM. Squamous cell carcinoma developing in trophic ulcer in leprosy. Ind J Lepr, 1988; 60: $380-4$.

21 Duvauchelle D, Goldstein N. Cauliflower growths in ulcers of leprosy: a question of malignancy. Hawaii Med $J, 1989$; 48: 129-31.

22 Riedel RG, Adhikari S. Malignancy in plantar ulcers in leprosy. Lepr Rev, 1990; 61: 400-1.

23 Girdhar M, Mohan L, Arora SK, Gupta M, Basu PK, Mishra SD, Mukhija RD. Squamous cell carcinoma developing in trophic ulcers of leprosy: report of 2 cases. Ind J Lepr, 1990; 62: 126-8.

24 Furuta M, Obara A, Ishida Y, Harada N, Ozaki M. Leprosy and Malignancy: Autopsy findings of 252 leprosy patients. Int J Lepr, 1990; 58: 697-703.

25 WHO Expert Committee on Leprosy. Sixth report. Technical Report Series. No. 768. WHO: Geneva, 1988. 


\title{
Epithelioma spino-cellulaire accompagnant des ulceres chroniques chex les lepreux: un examen de 38 cas consecutifs
}

\author{
J H Richardus ET T C SMITH
}

Résumé Une analyse fut faite respectivement des antécédents de 38 cas consécutifs d'épithélioma spinocellulaire (SCC) accompagnant des ulcères chroniques chez des lépreux traites entre 1981 et 1990 au centre de réadaptation McKean en Thailande du Nord. L'etude incluait 37 patients: 29 hommes et 8 femmes. La moyenne d'âge était de 60 ans, la durée moyenne de la lèpre était de 34 ans et la durée moyenne des ulcères était de 12 ans. La plupart des patients $(76 \%)$ venaient de colonies de lépreux. Les patients de type borderline-tuberculoïde (BT) étaient le plus fréquemment affectés $(63 \%)$, suivi de ceux souffrant de lèpre lépromateuse (LL) et de lèpre borderline-lépromateuse (BL) (16\%). Quatre patients (11\%) avaient des antécédents de SCC à d'autres extrémités. La présence de métastases à distance fut observée dans 2 cas $(5 \%)$, causant dans les deux cas le décès du patient. Le pied était l'endroit où le SCC se manifestait le plus fréquemment mais chez un patient, c'était le genou qui était atteint et dans deux autres cas, c'était la main qui était atteinte.

Le taux d'incidence de SCC dans le groupe à risque (patients lépromateux avec une invalidité de 1 et 2) est de 0,79 pour 1000 par an. Le SCC fut noté dans $1,8 \%$ de tous les cas admis à notre dispensaire suite à un ulcère. Le traitement est l'amputation radicale.

Le SCC dans le cas des ulcères chroniques chez les lépreux ne peut être considéré comme rare et c'est pourquoi une politique de prévention active de l'invalidité dans le cadre du programme de la lèpre est nécessaire.

\section{Carcinoma escamocelular en las ulceras cronicas de la lepra: un estudio de 38 casos consecutivos}

\section{J H RichaRdus y T C SMITH}

Resumen Se analizaron los antecedentes de 38 casos consecutivos de Carcinoma Escamocelular (SCC) que resultaron de las úlceras crónicas de pacientes leprosos tratados entre 1981 y 1990 en el McKean Rehabilitation Centre, Tailandia del Norte. El estudio comprendió 37 pacientes individuales; 29 hombres y 8 mujeres. El promedio de edad era 60 años, el promedio de duración de la lepra era 34 años y el promedio de duración de las úlceras era 12 años. La mayoría de pacientes (76\%) eran de colonias leprosas. Los pacientes con lepra tuberculoide (BT) marginal dudosa eran los que más eran af ectados, seguidos por los con lepra lepromatosa (LL) $(21 \%)$ y los con lepra lepromatosa marginal (BL) (16\%). Cuatro pacientes $(11 \%)$ tenían antecedentes de SCC en otras extremidades. Se observó la diseminación metastática en dos casos ( $5 \%)$, ambos casos culminando en la muerte. El sitio más común para la SCC fue el pie, pero se observó en la rodilla en un paciente y en la mano en dos otros.

La incidencia de la SCC en el grupo de más riesgo (pacientes leprosos con incapacidad de 1 y 2 ) se calcula en 0,79 por 1000 por año. Se observó la SCC en $1,8 \%$ de todos los casos que se recibieron para el tratamiento de úlceras en neustro centro. El tratamiento es por amputación radical.

No se debe considerar rara la SCC en los pacientes con úlceras crónicas ye esto hace resaltar la necesidad para una política activa para la prevención de incapacidad en el programa de la lepra. 